Devotees of John Milton's works are well acquainted with his Latin Defense of the People of England (1651) composed in rebuttal to the Royal Defense (Defensio Regia) written on behalf of Charles II by the then internationally famous French scholar, Claudius Salmasius. In his Defense, Milton teases Salmasius for sensitivity to the epithet Grammaticus, "grammarian":

Hamondum nuper regis hujus Sacellanum imprimis dilectissimum in libro quodam nugatorio nebulonem appellas, quòd is te Grammaticum appellavisset (Columbia edition, VII, 66-68).

Hammond, lately the most cherished chaplain of this king, you call, in some trivial book, nebulo, "knave," because he had called you Grammaticus, "grammarian."

This double-barbed remark was intended by Milton to sting both Hammond and Salmasius. To their contemporaries it was not obscure.

As for the Reverend Doctor Henry Hammond, persons then familiar with England's politics knew that he had been one of the very few who had spoken up publicly against the trial of King Charles I, in an open letter To the Right Honourable the Lord Fairfax and bis Councell of Warre, the Humble Addresse of Henry Hammond, January 15,1648/49; one of several which Milton characterized as the "Rhetorick of any puling Priest or Chaplain, sent as a friendly Letter of advice, for fashion sake in privat, and forthwith publisht by the Sender himself, that wee may know how much of friend there was in it" (Tenure of Kings and Magistrates, Columbia edition, V, 55).

It was therefore a sardonic pleasure for Milton to set two Stuart defenders into needling opposition to each other. That "trivial" book of Salmasius was indeed no world-shaking contribution, but in the circles where scholarship mattered it had received due notice, and in particular this sentence:

Nuper etiam quidam nebulo in Anglia, Capellanus ut audio Regis, Hammondus nomine, libro quem edidit de potestate Clavium, Salmasio iratus quod aliam quam ipsam sententiam probet ac defendat, haud potuit majus convitium quod ei dicere invenire, quam si grammaticum appellaret. (Claudius Salmasius, Specimen Confutationis Animadversionum Desiderii Heraldi Sive Tractatus de Subscribendis \& Signandis Testamentis, item De Antiquorum \& Hodiernum Sigillorum Differentia, Leyden, 1648, page 19).

Recently indeed some knave in England, Hammond by name, chaplain to the king, as I hear, in the book he published On the Power of the Keys, annoyed at Salmasius because he proves and defends an opinion different from his own, could not invent any greater insult to say to him than to call him "Grammarian" (Demonstration of Confutation of the Animadversions of Desiderius Heraldus, or a Treatise on the Signing and Sealing of Wills, Also the Differences between Ancient and Modern Seals). 
This gratuitous insult to Hammond, nebulo, was a digression from Salmasius' main focus of insult, Desiderius Hérault, with whom Salmasius was waging a scholar's feud (See: Johann Friedrich Jugler, Beyträge zur Juristischen Biograpbie, Leipzig, 1773, I, 370-380). For Hé-

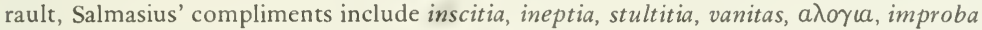
curiositas, mendacia (ignorance, ineptitude, stupidity, emptiness, absurdity, improper curiosity, falsehood), but for an opener in this book he devotes a first chapter to lecturing Hammond on the correct usage of Grammaticus among the Greeks and Romans, all because of some chance phrases in The Power of the Keys.

In that treatise (1647) Hammond had indeed several times referred to Salmasius as "this learned Grammarian" and "that learned Grammarian." He may indeed have really intended to be respectful, but in their context these phrases could easily be misinterpreted as derogatory in tone. At one point Hammond disputed a Greek text, which Salmasius read as "a new order" and which Hammond read as "youth of the Bishop": a kind of impeachment of his scholarship which was enough to make Salmasius bristle. Some of Hammond's other references were also less than flattering to Salmasius. Speaking of André Rivet, Hammond commented "then is his Illustriss. Salmasius deceived ..."; and presently Hammond inquired whether, in overthrowing the Epistles of Ignatius, Salmasius had not by the same token overthrown one of the epistles of Peter.

This discussion takes us back a few years to an earlier stage in the development of the English Revolution. In the Anglican-Puritan debate over church rule by bishops, a constant issue was the authority of the Epistles attributed to Ignatius of Antioch, according to tradition martyred by being thrown to wild beasts about 110 A.D. These epistles, in the versions available in the seventeenth century, included long passages on the respect due to bishops and on their jurisdiction within the church. Some of them consequently were invoked as testimony in favour of proving the antiquity of the authority of bishops going back to apostolic times.

Bishop Joseph Hall, in his Episcopacy by Divine Right Asserted, devoted the Second Part, Section 11, to "The Pregnant and Full Testimonies of the Holy Saint and Martyr, Ignatius, Urged." James Ussher, Archbishop of Armagh, in The Original of Bishops and Metropolitans Briefly Laid Down also drew from the epistles of Ignatius, and later reprinted the same material word for word in The Judgment of Doctor Rainoldes Toucbing the Original of Episcopacy, More Largely Confirmed out of Antiquity.

It was in opposition to these citations from Ignatius that Milton, in his reply to Ussher, Of Prelatical Episcopacy (1641) wrote:

I wonder that men teachers of the Protestant Religion, make no more difficulty of imposing upon our belief a supposititious offspring of some dozen Epistles, whereof five are rejected as spurious, containing in them Heresies and trifles... (Columbia edition, III, 88).

Milton's challenge was based on the 1623 edition of Ignatius by Nicholas Vedelius, $S$. Ignatii Episcopi Antiocbeni Et Martyris Quae Exstant Omnia Epistolas, in duos libros distincta, quorum prior continet Epistolas Genuinas, Alter Supposititias. Vedelius rejected five epistles as wholly spurious, and showed that the seven which he accepted as genuine were marred by passages of doubtful authenticity. 
Salmasius' opinion on these texts of Ignatius was familiar to protagonists on both sides of the debate in England, set forth on pages 251-252 of his pseudonymous Walonis Messalini De Episcopis et Presbyteris Contra D. Petavium Loiolitam Dissertatio Prima, 1641, a book well known on the continent, a book which Milton cited in his Reason of Cburch Government with a bow to "the late industry of the learned Salmatius." In Salmasius' judgment, those epistles were so full of interpolations, so full of anachronistic references to rites and customs of later date, and so rhetorically in contrast with the simplicity of apostolic style, that they could not have been written by that Ignatius to whom they were ascribed. In this view, which in effect totally nullified their authority, he was seconded by another prominent scholar of the Reformed persuasion, David Blondel.

The pro-bishop party in England was eager to salvage as much of Ignatius as possible, because the parts accepted by Vedelius still reinforced their position. Bishop Hall, in a scholarly sense, weakened his case by urging the validity of some passages marked as unacceptable by Vedelius. The anti-episcopal party, which in 1641 counted Salmasius and Blondel as allies, insisted that if so much of the epistles were spurious, then none of them could have weight as evidence.

Archbishop Ussher, who was devoted to scholarship as well as to partisanship, was therefore not inclined to simply rely on the work of Vedelius and his predecessors. He had found two old Latin manuscripts in England, with variant texts, and for some years he worked to edit a version of his own. On September 30, 1640 he wrote to Samuel Hartlib telling of his labours on this project, and of his efforts to locate in the Ottoman Empire a text in Syriac or some other Levantine tongue, in hopes of obtaining a still older version. He published his work at Oxford in 1644 in Polycarpi et Ignatii Epistolae, printed in parallel with Vedelius' Greek text, using red and black type to highlight the variations. In this book Ussher takes courteous notice of Salmasius' objections, referring to him as eruditissimi illius viri and vir doctus (1644, cxxxvi, Ixvii); Ussher even went so far as to send a copy of his prefatory material to Salmasius with a respectful note, hoping that his disagreement would not be offensive (Ussher's letters were printed in 1686 by Richard Parr, The Life of the Most Reverend Fatber in God, James Usher, etc.).

Somewhere along these years Ussher became aware of the existence of still another and differing manuscript version of Ignatius in the library of the Medici at Florence. Through the help of Americus Salvetus, then resident envoy in England representing Ferdinand II of Tuscany, a transcript of this manuscript (which among those scholars was simply called the Medicean $\operatorname{codex})^{1}$ was made available to Isaac Vossius, who published this text in Amsterdam in 1646. This find was an event of much excitement in the scholarly world. Blondel for one hastened to read Vossius' materials when they were still in manuscript. He had himself dealt briefly with Ignatius and Ussher's edition in his Apologia Pro Sententia Hieronymi de Episcopis et Presbyteris (March, 1646).

Ussher took cognizance of Vossius' work by issuing a new book, Appendix Ignatiana, published 1647 by George Thomason. In this volume he pays a compliment to Henry Hammond, with whom he had become acquainted about 1643. With Salmasius and Blondel, Ussher was becoming impatient. He does not name them, but refers to them as "duos magni nominis viros," those two men of big name, who still consider all of Ignatius' Epistles to be an imposture. Ussher seems in this regard to share the mood of Hammond in the Power of the Keys, published the same year; and also seems vexed by the circulation of private 
and public letters by Blondel criticizing his work.

Ussher and Hammond discussed these matters in correspondence, and Hammond drafted a reply to Blondel, which he submitted to Ussher. Ussher wrote back:

I have read, with great delight and content, your accurate answer to the Objections made against the Credit of Ignatius his Epistles; for which, as I do most heartily thank you, so am I moved thereby further to intreat you to publish to the world in Latin, what you have already written in English, against this Objector, and that other, who for your pains hath rudely requited you with the bare appellation of Nebulo for the assertion of Episcopacy, to the end it may no longer be credited abroad, that these two have so beaten down this Calling that the defence thereof is now deserted by all Men, as by Lud. Capellus is intimated in his theses of Church-Government at Sedan lately published. (Parr, 1686, page 542). ${ }^{2}$

Hammond was encouraged to continue along these lines, but it seems he was rather taken aback by Ussher's reference to the nebulo epithet. From a later letter by Ussher, it may be inferred that the epithet was news to Hammond, and that he wrote asking Ussher what it was all about. Ussher replied:

\section{Good doctor:}

I received heretofore, by your direction, from Mr. Allestree, the Greek Passage of Irenaeus, and yesterday your most accurate descanting on the same, for which I return unto you very hearty thanks, being very glad also to understand by your letter of the 20th of August, therewith received, that you have a thought of making an entire dissertation for the vindicating of Ignatius his epistles: which together with your Treatise of Episcopacy in Latin, enlarged with such additions as you mention of Act. 20 and the Ancyran Canon, 1 hold would be to exceeding good purpose. The new title wherewith you were dubbed, of Sir Knave, is in the railing book writ expressly against Desiderius Heraldus; which having but look'd on, I sent to young Heraldus, the other's Son, who hath not hitherto restor'd the same to me. I pray God to bless you in all your Godly Endeavours, in whom I ever more rest,

Your ever loving Brother,

$$
\text { Ja. Armachanus (Parr, 1686, page 541) }
$$

Hammond's work came out in 1651 as Dissertationes Quatuor Quibus Episcopatus Jura ex S. Scripturis et Primaeva Antiquitate Adstruuntur Contra Sententiam D. Blondelli et Aliorum. Whether Hammond was inclined to counterattack on the score of that nebulo epithet or not, by the time he had that book ready, it had become quite impolitic to do so. By 1651, as Hammond takes notice in his preface, Salmasius had become the defender of the royal cause of Charles II, and in this new status had shifted his ground from opposition to episcopacy to using some of the arguments of its defenders. Hammond's preface extends congratulations to Salmasius for his reversal in Defensio Regia.

As for Milton's rebroadcasting of that epithet, it was even more discreet to remain silent. Milton was an official of the government which came to power by defeating Hammond's 
party in politics and in battle. Milton's book was a state-sponsored publication. Hammond demonstrated the same discretion in his A Letter of Resolution of Six Quaeres, London, c. 1652 , in which he dealt as a clergyman with questions of morality and conduct. Third of these queries concerned polygamy and divorce, two practices which in the conservative theological mind were then closely linked, and both opposed by Hammond. Milton was then notorious in England as the advocate of legalizing the right to divorce. Hammond deals with Milton's views, but never names Milton:

Sec. 44. Having gone thus far, I should soon be at the end of my gesses, were there not some pretensions of other men, who like not to have their liberties retrench'd, though by Christ himself, which may deserve to be a while considered. And the considering of them will be the most ingrateful part of this task; yet that which must be undergone lest, having offered their reasons and exceptions against the Doctrine of the Cburch, and expressly of Christ himself, they be permitted to that dangerous temptation, of thinking themselves successful in the attempt, and so that prove to some men a more persuasive reason to believe their wishes, then any yet hath been produced.

Sec. 45. A plea for Divorces). The first open attempt that I remember that way, was made in a Discourse purposely on that Subject, and presented to the Parliament, at the beginning of these licentious times; and the special artifice made use of, was that, of bringing back Christ unto Moses, of interpreting the restraint laid on this matter in the New Testament, by analogie with the Judaicall permission in the Old.

Hammond devoted a much longer discussion to the views of John Selden, naming him and citing his book, Uxor Ebraica. Undoubtedly Selden at that time had a far greater reputation, not only in England but even more on the continent, where his writings on marriage were authoritative among Protestants generally. He was also a safer target.

Unfortunately for himself, in preparing his 1651 Dissertationes Quatuor, Hammond incautiously permitted some phrases to remain that reflected his previous negative attitude to Salmasius. In his Chapter XXIV, touching on the aid formerly given by Blondel and Salmasius to the Presbyterian cause in England, Hammond included a parenthetical phrase "(quibus illecebris adducti nescio)," - "by which inducements drawn I do not know." This phrase might be read with mild intent or with malicious intent. As a result of this unguarded phrase, Hammond was not going to be permitted to forget the insult of Salmasius' nebulo.

Before we come to that sequel, we must first turn to the Provincial Assembly of London ministers, who felt impelled to answer Hammond's dissertations with Ius Divinum Ministeri Evangelici, or the Divine Right of the Gospel Ministry, London, 1654. These ministers, among whom was Edmund Calamy, have from their own standpoint learned nothing and forgotten nothing. It disturbed them that Hammond had not been convinced by the Smectymnuus (anti-bishop) tracts put out by Calamy and his friends a dozen years before. With equal obtuseness they recommended that Hammond "should do well to answer also to what the learned Archbishop of Armagh hath written at large about these epistles" (Ius Divinum, 1654, page 109).

Reading this, Hammond wrote to Ussher, May 16, 1654, 
I could not but smile when I was of late required by the London-Ministers to answer the Objections you had made to the Epistles of Ignatius. The Printer will shortly give you an account of the Return I have made to it. I find now in another Caviller against those Epistles, a Testimony out of St. Jerom, Dial. 3 cont. Pelag. (Ignatius vir Apostolicus \& Martyr Scribit audacter, Elegit Dominus Apostolos qui super omnes homines peccatores erant) which 1 find not in his Epistles. Doth your Grace remember any thing of it? If it be not troublesome, I beseech you impart one word concerning it to

Your most humble servant

H. Hammond (Parr, 1686, page 541).

The other "caviller" is not identified by Hammond, but we find that specific cavil on Sig. C2 of the preface of a book by John Owen, The Doctrine of the Saints Perseverance Explained and Confirmed, etc., Oxford, 1654. Owen, a minister associated with Cromwell and his Council of State, digressed to attack Hammond in his preface which has no heading there but is designated on the prolix title page of the volume as $A$ Discourse touching the Epistles of Ignatius, The Episcopacy in them asserted, and some Animadversions on Dr. H. H. bis Dissertations on that Subject.

Hammond did not say so to Ussher in his letter, but Owen had indicted him on eight counts, in detail, even recalling the disagreement with Salmasius over that Greek phrase, but most sharply cutting at him with this twin edged blade:

Of his two learned Antagonists one is dead, and the other almost blind, or probably they would have dealt not much more gently with the Doctor for his Parentbesis (quibus illecebris adducti nescio) then one of them formerly did [bere Owen cites Salmasius against Heraldus, quoting the 'nebulo' passage given above] for his tearming him a Grammarian, yet indeed of him (such was the hard entertainment he found on all hands) it is by many supposed that he was illecebris adductus (and they stick not to name the bait he was caught withall) wrought over in a manner to destroy the faith of that, which he had before set up and established.

Owen here has used his variant of Milton's two-pointed tactic, stinging Hammond ('nebulo') and at the same time registering a posthumous hit at the late Salmasius for having shifted from support of the presbyterial to the episcopal camp. Owen does not cite Milton's Defensio for the gossip about the golden coin allegedly paid to Salmasius for the Defensio Regia, but he need not have depended on Milton's book alone for that rumour.

Once again Henry Hammond was in an embarrassing dilemma. What could he say that might wipe off the stain of that nebulo-knave epithet, and what could he do that would negate the inference from his parenthetical remark that Salmasius was venal? He presently gave his answer, rather contritely, and at inordinately great length in An Answer to the Animadversions on the Dissertations touching Ignatius' Epistles and the Episcopacy in them Affected (1654). He repeats the text of Owen's criticisms in full and answers with apologetics so ponderous and so repetitious as to discourage any other of those longwinded pulpiteers from entering the issue. Some shorter extracts will suffice for now: 
... I knew how Salmasius had dealt with me in that passage to Heraldus, before my setting about the Dissertations; that this was so far from imbittering my stile against him, that I did the more carefully watch over my pen, not to say any reproachful thing of him, but rather to commend his second thoughts in the matter of Presbytery, which he was willing to testifie in some passages of his Defensio Regia [Hammond continues with a bomily on a Greek text from Ignatius "To their anger do ye return meekness."]

Secondly: That my terming Salmasius formerly a Grammarian, with the addition of Learned, was in the sincerity of my heart, meant as a title not of diminution, but of honour to him [Hammond bere praises Salmasius' learning, his skill in Latin and Greek words and phrases; discusses "grammatike" and its three parts, "tecbnike, exegetike, kritike,"] and lastly that [Salmasius] being neither Divine, nor Physician, nor Lawyer by profession, I could not fitly make either of those his title, I thought it most agreeable to all these reasons to stile him learned Grammarian, especially having so little reason, as I then had, to commend his knowledge in Theologie. This it seems was so represented to him from England, that having no other reason (that I am conscious of) to quarrel with my bebaviour toward him, he was content to reproach me upon that stile: and all that I shall say to it, is that I had rather be in the foulest manner reproacht without cause, than to be commended for ill doing, or to be justly censured by any.

Thirdly, when I said of him and Blondel (quibus illecebris adducti nescio) I do not think myself to have wronged them, or used them contumeliously. Not wronged them, because I verily believe there were motives properly stiled illecebrae (I mean not bribes from England) which brought them to doe what they did: And as I did not think fit then to expresse those motives, being 1. matters of fact, of which at this distance, I could not have perfect Knowledge or evidence and so could truly say (quibus nescio) and 2. being personal matters, which I love not to publish, farther than the matter it self reveales and declares them; so I shall not choose now out of season, and less pertinently to inlarge on on that matter: I shall only add that Salmasius lived and Blondel saw, many moneths, some years after the publisbing of the Dissertations, and neither of them thought fit to fall into such passion so causelesly, nor, that I ever heard, sent the Author of these Animadversions their Letters of Attorney to do it for them....

How justly the many which he mentions, have supposed that he was illecebris adductus, and from what evidence they name the bait, or with what trutb it is suggested, that hee bad ever set up and establisht that faith which bis Defensio Regia endeavoured to destroy, are things so far removed from the subject before us, the autbority of Ignatius's Epistles, and so unlikely to be concluded by our disputes, that I think we may by consent let them alone. Otherwise, the then present lownes, and improsperity of the cause, which he defended, would offer it self for a very competent argument to infer, the love of truth more than the expectation of any temporal advantage, to have perswaded the writing of it.

Milton, and Salmasius, and Hammond are dust, and dusty from disuse are their neglected tomes; still in tracing out these long forgotten trivia, scholarship may permit itself a half smile at a history whose bald recounting adds up to a satire on the foibles of learned men. 


\section{Notes}

1 It will be remembered that in 1639 Vatican librarian Lucas Holstenius asked John Milton, then on his way to Florence, to check at the library there on a certain "Medicean codex": but which? The muse of history is a tease. In any case, Milton was unable to fulfill the request and suggested that G. B. Doni try it. It was Giovanni Battista Doni, who had become head of the Medici library, whom Isaac Vossius later thanked, in the preface to his 1646 Epistolae Genuinae S. Ignatii Martyris quae nunc primum lucem vident ex biblioteca Florentina, for the text of his "Medicean codex."

2 Ussher is referring to the Theses Theologicae de Episcopi et Presbyteri Discrimine. Praeside D. Ludovico Capello. Respondente Abrabamo Gilberto, Pictone, included in Theses Theologicae in Academia Salmuriensi Variis Temporibus Disputatae sub Praesidio D. D. Virorum S. Theologiae Professorum Lud. Capelli, Mos. Amyraldi, Pars Tertia et Ultima. Salmurii, apud I. Desbordes, MDCLI, also republished in several later editions.

To establish the exact dates of this letter and the one following would require seeking out the manuscripts, if indeed they are extant. In Parr, the letter "I have read" bears the date "July 21." The letter "I received heretofore" bears the date "Apr. 30, 1649" but the content requires "August 30." We cannot be certain that " 1649 " is more correct than, possibly, "1648." 